\section{LECTORI SALUTEM!}

\section{Kedves Olvasó!}

Tisztelettel, örömmel és barátsággal üdvözöljük Önt az OxIPO - interdiszciplináris tudományos folyóirat legelső számának Olvasói között!

E meglehetősen szokatlan címú folyóirat mögött húzódó alapítói, kiadói és szerkesztói szándék az, hogy a hagyományos, egy-egy szúkebb értelemben vett tudományágra fókuszáló kutatások mellett nyilvánosságot biztosítsunk a diszciplináris kereteken átívelő, több tudományág múvelőinek együttmúködésében megvalósuló kezdeményezéseknek is. Ezt legalább három okból tartjuk fontosnak:

Egyrészt az univerzumot tudományágakra szabdalni bizonyos szempontból praktikus ugyan (hiszen kisebb egységekben fedezhetjük fel, oktathatjuk és taníthatjuk azt), ám időnként szintetizálnunk kell az egymástól elszeparált tudományterületeken szerzett ismereteinket. Ugyanis, ha ezt nem tesszük meg, akkor lényegében úgy járunk, mint az egyszeri diák, aki kiváló feleletet adott ugyan a „Halak úszóhólyagja” címú témakörből biológia órán, s jeles osztályzatot kapott fizika órán is a „Felhajtóerô” című témakörből, ám arra a kérdésre nem tudott válaszolni, hogy mi lehet az összefüggés a két témakör között. Ố sajnos nem tudta szintetizálni a biológia és a fizika tantárgybeli tudását. Vele ellentétben számos világszerte géniusznak tartott elme tudományos sikereinek egyik titka éppen az volt, hogy át mert és tudott lépni a tudományok közötti - valójában nem is olyan merev - határokon. Talán legközismertebb képviselőjük Leonardo da Vinci: gondoljunk többek között denevérszárny-szerű repülő gépezeteire (= biológia+ mechanika). Bízunk benne, hogy e folyóirat elősegitheti és facilitálhatja majd az interdiszciplináris kutatásokat.

$\mathrm{Az}$ interdiszciplináris folyóiratunk alapítása mögött álló másik ok az, hogy e sorok írása idején nyílvántartott 1919 hazai tudományos folyóirat közül mindössze 3 képviseli címében is az interdiszciplinaritást, ám ezek közül csak kettő múködik még napjainkban is (lásd: a Magyar Folyóiratok Tartalomjegyzékeinek Kereshető Adatbázisát Építők Egyesületének a MATARKA-nak a honlapját: www.matarka.hu). Természetesen egy folyóirat akkor is közöl(het) interdiszciplináris jellegú tanulmányokat, ha címében nem tesz erre irányuló utalást, ám mégis jelzés értékű e kifejezés ritkasága a folyóiratcímekben. Jelen folyóirat címében is felvállalt és doi: 10.35405/OXIPO.2019.1.5

hirdetett módon törekszik szolgálni az interdiszciplináris orientációjú kutatásokat, kutatókat.

Végül a folyóirat alapításának oka az is, hogy minél több kutató számára tegyük lehetôvé azt, hogy nyilvánosságra hozzák tudományos eredményeiket. Ebből a szempontból e lap múködtetése a kiadó, a K+F Stúdió Kft. (web: www.kpluszf.com) társadalmi felelősségvállalási tevékenysége (CSR) keretében megvalósuló nonprofit tudománysegítő tevékenység. Az interdiszciplinaritás ebből a szempontból azért lényeges, mert így nemcsak egy szúkebb értelemben vett tudományterület kutatóinak, hanem a lehetô legtágabb potenciális Szerzői körnek tudunk publikációs lehetôséget biztosítani.

Ezzel el is jutottunk ahhoz a problémához, ami a legnagyobb kihívást jelentette a folyóirat tervezésekor... Nevesen: hogyan kerülhetjük el, hogy miközben jó szándékkal törekszünk a tudományos sokszínűségre, végeredményként mégse váljon a lap igen-igen különböző témájú tanulmányok random módon egymás után közölt, összefüggéstelen, kaotikus halmazává. A megoldás végül nyilvánvalóvá vált: szükség van egy általános rendezôelvre, ami a legkülönbözőbb tudományterületek és témák esetében alkalmazható, értelmezhető. E rendezőelvként jelen folyóiratban az OxIPO-modellt választottuk, miszerint: a Teljesítmény $=$ Organizáció $\mathrm{x}$ (Input $\mathrm{x}$ Process x Output). Az OxIPO-modell olyan elméleti keret, amely a tudományok széles körében nyújt lehetőséget személyek, produktumok, folyamatok, jelenségek elemzésére, diagnosztikájára, bejóslására, tervezésére, irányítására. Az OxIPO-modell a Magyar Tudományos Akadémia 2017-ben közreadott tudományági nómenklatúrája minden tudományterületéhez kapcsolható szervező elv. A folyóirat további tanulmányaiban megismerhetjük e modell sokszínủ alkalmazási lehetőségét, s részleteit.

A fentiek eredményeként jött végül is létre a kiadói tervek szerint negyedévente megjelenő Open Access (nyílt hozzáférésû) internetes periodika, az OxIPO - interdiszciplináris tudományos folyóirat...

....amihez ezúton kívánunk jó olvasást, s amelynek Szerzői sorába ezúton is invitáljuk Önt!

Üdvözlettel,

Mező Ferenc alapító fôszerkesztő 